\title{
OBSERVATIONS ON THE DRAINAGE OF A GLACIER-DAMMED LAKE IN NORWAY
}

\author{
By N. Aitkenhead \\ (University of Durham Exploration Society, King's College, Newcastle upon Tyne)
}

\begin{abstract}
The behaviour of a Norwegian glacier-dammed lake, before, during and after drainage in 1957 is described. The evidence of former shoreline terraces is interpreted and possible drainage mechanisms are discussed.
\end{abstract}

Résumé. On décrit le comportement d'un lac norvégien obstrué par un glacier et qu'on a observé avant et après le drainage effectué en 1957 . On émet une interprétation d'anciens rivages étagés mis à vue pendant l'évacuation des eaux. On discute aussi les divers mécanismes de drainage qui peuvent se produire.

Zusammenfassung. Es wird das Verhalten eines norwegischen durch einen Gletscher abgedämmten Sees während und nach der Entwässerung im Jahre 1957 beschrieben. Der Beweis für ehemalige Ufer-Terrassen wird geführt, und ein möglicher Mechanismus der Entwässerungsvorgänge wird besprochen.

\section{INTRODUCTION}

During the summers of 1956 and 1957 members of expeditions sponsored by the University of Durham Exploration Society made observations on a lake dammed by Strupbreen in Norway. Strupbreen and its dammed lake are situated in the Lyngen Peninsula (lat. $69^{\circ} 39^{\prime}$ N., long. $20^{\circ}$ I $2^{\prime}$ E.).

Rapid fluctuations in the water-level of this lake have been reported by a number of observers, including M. M. G. Hastings and C. Slingsby in 1898 , and Olav Liestøl in $1953 \cdot{ }^{x}$ Their reports suggest that the lake had periodically drained in a sudden and rapid manner.

During July and August 1956 the lake level fluctuated only a few centimetres about a general level of $448 \mathrm{~m}$. above sea-level with a net fall of $60 \mathrm{~cm}$.* The lake then was about $\mathrm{I}, \mathrm{I} 00 \mathrm{~m}$. long and $300 \mathrm{~m}$. wide with an area of $285, \mathrm{I} 20 \mathrm{~m} .^{2}$.

\section{The Lake Before, During and After Drainage}

On 2, 3 and 4 August 1957 a sudden drainage was observed.* Before this occurred careful daily measurements had been made of the lake level (Table I).

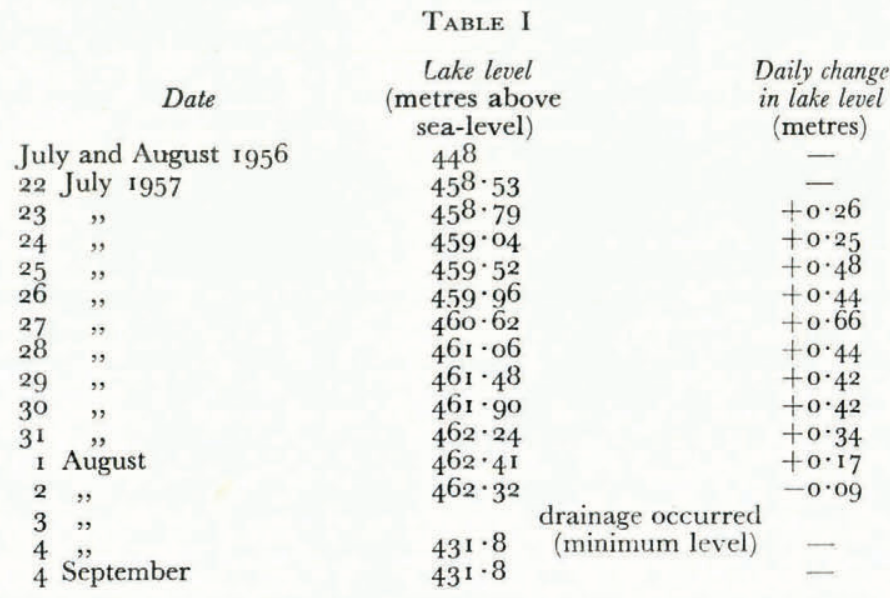

* A description of these events can also be found in reports on the University of Durham Exploration Society expcditions to Norway in 1956 and 1957. Copies of these reports have been deposited at: the Scott Polar Research? Institute. Cambridge; the Library, University of Durham; the Royal Geographical Society; Tromsø Museum; Norsk Polarinstitutt, Oslo. 
The average daily rise in level was $0.3^{8} \mathrm{~m}$., representing an increase in volume of over I08,000 $\mathrm{m} \cdot 3 /$ day. When these figures are compared with the almost stable lake level during the corresponding period in $195^{6}$ it can be seen that Strupbreen was efficiently damming the lake.

The drainage of the lake began on 2 August almost imperceptibly with a fall in level of $9 \mathrm{~cm}$. During the night crashing and grinding noises were heard coming from the direction of the lake and by $12.30 \mathrm{hr}$. the following day the level had already fallen over $10 \mathrm{~m}$. As the lake level fell, large blocks of ice calved off the now unsupported glacier ice-front. These, together with large snow blocks and lake ice, gradually became haphazardly stranded on the steep unstable shores of the lake. Simultaneously a large terminal moraine built from material deposited by the distributory tongue of Strupbreen when at its last maximum in the eighteenth century was revealed. This moraine split the lake into two and soon a strong current, flowing from the higher to the lower lake, was sweeping through a narrow channel at the western end of the moraine.

By 4 August the lake level reached its minimum (see Fig. I and the photograph in Fig. 2, p. $6 \mathrm{I}$ I), having fallen by $30.6 \mathrm{r} \mathrm{m}$. in 54 hours. The volume of water lost from the lake during drainage was about $9 \times 10^{6} \mathrm{~m} \cdot{ }^{3}$ and this drained at an average rate of $45 \mathrm{~m} \cdot{ }^{3} / \mathrm{sec}$. The flow of the river emerging from the snout of Strupbreen about $I \frac{1}{4} \mathrm{~km}$. to the east was greatly enlarged. After plunging over a $300 \mathrm{~m}$. cliff the water with its load of splintered ice flowed harmlessly into Lyngenfjord in an adequate channel, which could only have been made by even greater floods from past lake drainages.

No new rise in the water level in the lake took place up to 4 September 1957, and a photograph taken in August $195^{8}$ by Mr. Bruce Aitken showed that the lake level was still at its 1957 minimum, thus indicating that the subglacial drainage channel was still open.

\section{Former Shoreline Terraces}

After the lake had drained the stable 1956 lake level was represented by a distinct terrace in the scree slopes surrounding the lake. An additional indication of stability was a deposit of rock flour on the old lake bed below the 1956 shoreline. Above the 1956 shoreline a whole set of terraces was clearly seen on the scree slopes, particularly where these were stable and where the scree material was of the right size to be worked by wave action. These higher terrace were at heights of $19 \cdot 0,25 \cdot 3,28 \cdot 3,29 \cdot 8,30 \cdot 6,36 \cdot 7,48 \cdot 3$ and $50 \cdot 5 \mathrm{~m}$. respectively above the 1956 terrace. Since this was formed during a period of lake level stability, it is probable that the higher terraces also represent stable levels when both the lake and Strupbreen were much larger than at present. It is clear that in the past drainages occurred periodically with successively lower levels of stability, but there is no evidence as to the time interval between them.

\section{Discussion of Possible Drainage Meghanisms}

The observations on lake levels support the theory that drainage is initiated by floating of the glacier front, thus allowing lake water to escape between the glacier ice and the bedrock. The maximum lake level prior to drainage reached the top of the ice barrier and only $7.90 \mathrm{~m}$. below the lowest point on the side of the glacier at which direct overflow could have occurred. This level of water was in fact sufficient to cause the immediately adjacent part of the glacier front to float. Although the theoretical conditions were satisfied for the initial escape of the water no new light was thrown on how the subglacial channel was kept open despite the immediate reduction in water pressure. Liestøl ${ }^{\top}$ has suggested melting by the outflowing lake water as a possible mechanism. Assuming that the ice is initially raised by the lake, it is unlikely that it would be dropped into exactly the same position and the resulting contact of the uneven ice and bedrock surfaces would provide a passage for the water. Furthermore, the outflowing water contained many ice fragments and if some larger pieces 
became wedged in their passage through the subglacial channel they would support the sagging roof.

The timing of the 1957 drainage poses another problem. Why should the lake level remain stable for one year and probably longer and then rapidly increase, thus causing a drainage? Clearly, during periods of stability the flow of water into the lake must equal the outflow. Outflow might take place either through subglacial channels or along the channel in the gap between ice and rock at the side of the glacier. Such a gap was seen and although no actual outflow of water could be seen a sound suggesting a considerable volume of running water could be heard. In both the above possible modes of outflow the flow of water would gradually cause the channels to become enlarged by melting. This would result in a corresponding gradual fall in lake level. In 1956 the lake level did in fact fall by about $60 \mathrm{~cm}$.

When the lake level rose in 1957 prior to drainage the channels by which outflow occurred in 1956 must have become partially or completely blocked. The simplest and most probable way by which this might have occurred was by the freezing of water in the subglacial channels together with infilling of the gap between ice and bedrock by drifted snow.

The fact that such a blockage does not occur every year suggests that exceptional weather conditions are required. It may be significant that the winter and spring of 1957 were exceptionally severe. Local reports suggest that a sudden heavy thaw occurred in March followed by a severe freeze-up, and it is conceivable that the subglacial channels became blocked during this freeze-up.

Clearly more detailed observations are necessary to establish the precise relationship between the lake levels and fluctuations in local weather conditions.

MS. received 9 October 1959

\section{REFERENCE}

I. Liestøl, O. Glacier dammed lakes in Norway. Norsk Geografisk Tidsskrift, Bd. 15, Ht. 3-4, 1955-56, p. 122-49. 


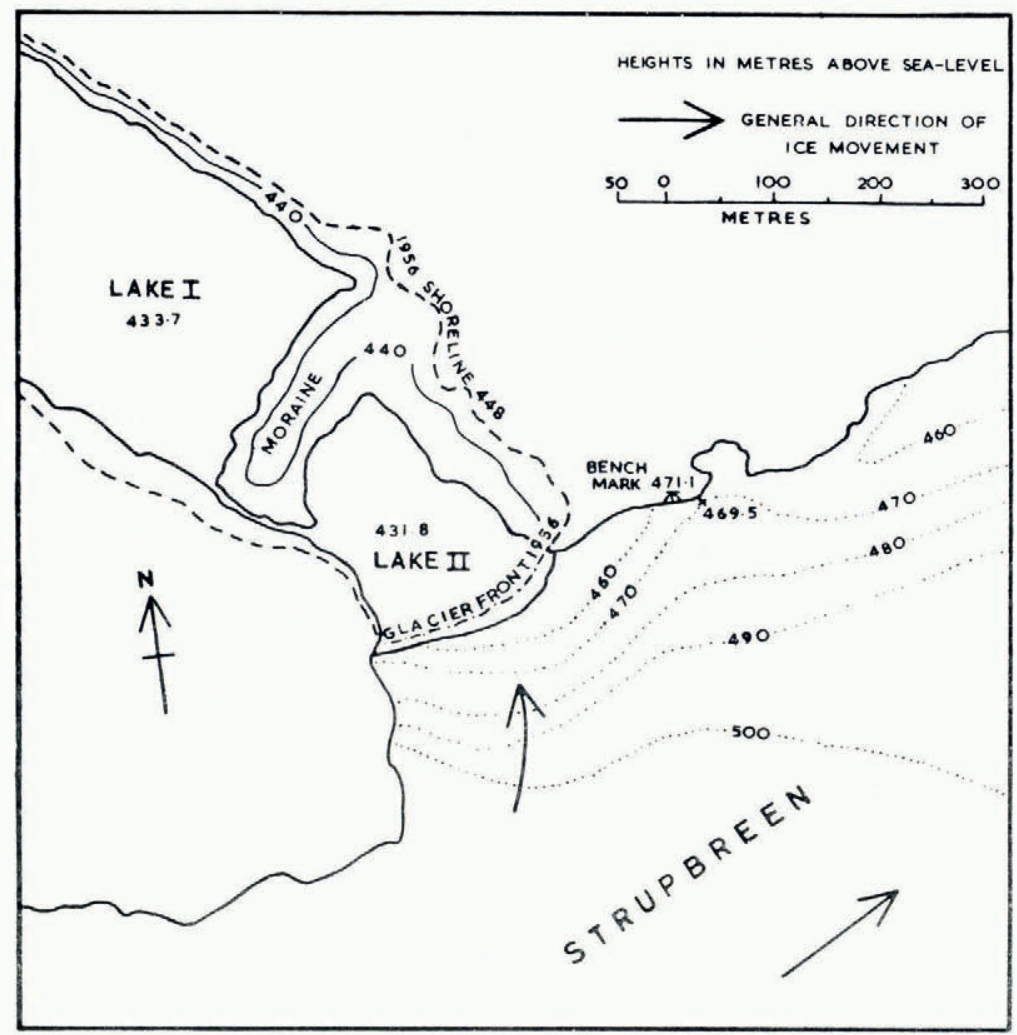

Fig. I. Part of Strupbreen and the glacier-dammed lake after diainage in 1957 (see N. Aitkenhead, p. 508)

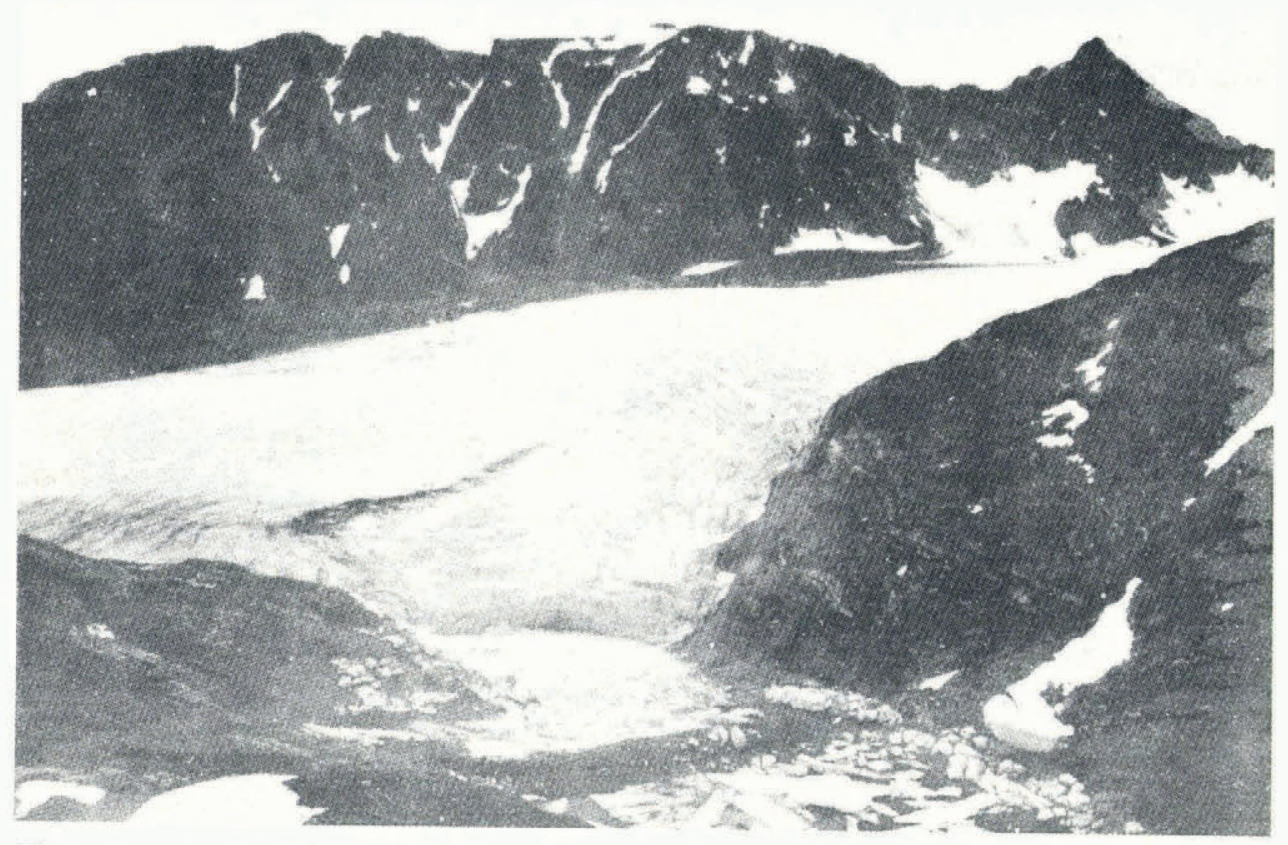

Fig. 2. A view of Strupbreen and part of the glacier-dammed lake showing the large terminal moraine uncovered after drainage in 1957 (see N. Aitkenhead, p. 508) 